\title{
Article \\ Clonal Dissemination of Plasmid-Mediated Carbapenem and Colistin Resistance in Refugees Living in Overcrowded Camps in North Lebanon
}

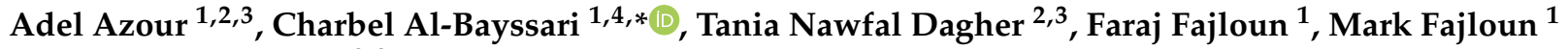 \\ and Jean-Marc Rolain 2,3,*
}

\section{check for} updates

Citation: Azour, A.; Al-Bayssari, C.; Dagher, T.N.; Fajloun, F.; Fajloun, M.; Rolain, J.-M. Clonal Dissemination of Plasmid-Mediated Carbapenem and Colistin Resistance in Refugees Living in Overcrowded Camps in North Lebanon. Antibiotics 2021, 10, 1478. https://doi.org/10.3390/ antibiotics 10121478

Academic Editor:

Ágnes Pál-Sonnevend

Received: 14 October 2021

Accepted: 29 November 2021

Published: 2 December 2021

Publisher's Note: MDPI stays neutral with regard to jurisdictional claims in published maps and institutional affiliations.

Copyright: (c) 2021 by the authors. Licensee MDPI, Basel, Switzerland. This article is an open access article distributed under the terms and conditions of the Creative Commons Attribution (CC BY) license (https:// creativecommons.org/licenses/by/ $4.0 /)$.
1 Faculty of Sciences 3, Lebanese University, Michel Slayman Tripoli Campus, Ras Maska 1352, Lebanon; adelazour3@gmail.com (A.A.); faraj_fajloun@hotmail.com (F.F.); mark.fajloun1999@gmail.com (M.F.)

2 IRD, APHM, MEPHI, IHU-Méditerranée Infection, Aix Marseille Univ., 13005 Marseille, France; tania_nawfal28@hotmail.com

3 Faculté de Médecine et de Pharmacie, 19-21 Boulevard Jean Moulin, CEDEX 05, 13385 Marseille, France

4 Genomic Surveillance and Biotherapy Laboratory, Faculty of Sciences, Lebanese University, Ras Maska 1352, Lebanon

* Correspondence: Charbelalbayssari@hotmail.com or Charbel.albayssari.1@ul.edu.lb (C.-A.B.); jean-marc.rolain@univ-amu.fr (J.-M.R.); Tel.: +961-70-177-401 (C.-A.B.); +33-4-1373-2401 (J.-M.R.)

\begin{abstract}
Carbapenem and colistin-resistant bacteria represent a global public health problem. Refugees carrying these bacteria and living in inadequate shelters can spread these microorganisms. The aim of this study was to investigate the intestinal carriage of these bacteria in Syrian refugees in Lebanon. Between June and July 2019, 250 rectal swabs were collected from two refugee camps in North Lebanon. Swabs were cultured on different selective media. Antibiotic susceptibility testing was performed using the disk diffusion method. Carbapenemase-encoding genes and mcr genes were investigated using real-time polymerase chain reaction (RT-PCR) and standard polymerase chain reaction (PCR). Epidemiological relatedness was studied using multilocus sequence typing (MLST). From 250 rectal swabs, 16 carbapenem-resistant, 5 colistin-resistant, and 4 colistin and carbapenemresistant Enterobacteriaceae were isolated. The isolates exhibited multidrug-resistant phenotypes. Seven Klebsiella pneumoniae isolates harboured the bla $a_{\mathrm{OXA}-48}$ gene, and in addition four K. pneumoniae had mutations in the two component systems $\mathrm{pmrA} / \mathrm{pmrB}$, phoP/phoQ and co-harboured the $b l a_{\mathrm{NDM}-1}$ gene. Moreover, the bla $a_{\mathrm{NDM}-1}$ gene was detected in six Escherichia coli and three Enterobacter cloacae isolates. The remaining five E. coli isolates harboured the $m c r-1$ gene. MLST results showed several sequence types, with a remarkable clonal dissemination. An urgent strategy needs to be adopted in order to avoid the spread of such resistance in highly crowded underserved communities.
\end{abstract}

Keywords: refugees; Enterobacteriaceae; NDM-1; mcr-1

\section{Introduction}

Antimicrobial resistance (AMR) has increased markedly in recent years. This is particularly important when facing complex infections in humans [1]. AMR is expected to result in severe mortality and economic losses that will increase the cycle of poverty [2]. This global public health concern causes huge clinical and economical losses, mainly in developing countries [3]. Thus, the Centers for Disease Control and Prevention (CDC) and the World Health Organization (WHO) have recognised AMR as an urgent and global crisis and threat $[4,5]$.

Carbapenems are a group of $\beta$-lactam drugs that are often used as last resort antibiotics to treat infections arising from multidrug-resistant (MDR) Gram-negative bacteria [6] Unfortunately, carbapenemase-producing Gram negative bacteria have become a major concern around the world [7-9]. They are a growing concern because they confer resistance 
to $\beta$-lactam antibiotics and other classes of antibiotics such as aminoglycosides, fluoroquinolones, and cotrimoxazole [10]. This reduces the possibility of treating infections due to such multi-resistant organisms [11].

Currently, carbapenemases in Enterobacteriaceae are found mainly in Klebsiella pneumoniae, E. coli, and other enterobacterial species, with a greater prevalence in southern Europe and Asia than in other parts of the word [6]. New Delhi metallo- $\beta$-lactamase-1 (NDM-1) is the most frequent carbapenemase found in Asia [12]. A recent study conducted in Nepal in 2019 [13] showed that the prevalence of MDR bacteria was 58\% (199/343 isolates), with a prevalence of $12.5 \%$ for carbapenemase-producing bacteria and 3\% for colistin-resistant bacteria. Interestingly, a study published in 2021 [14] in the same country, showed the rapid dissemination of carbapenem-resistant bacteria. From a total of 58 K. pneumoniae isolates, $60 \%(35 / 55)$ were carbapenem resistant with NDM-1 being the most dominant carbapenemase $(80 \%)$.

On the other hand, K. pneumoniae carbapenemase (KPC) is mainly found in the United States and in Europe (France, Greece, and Italy) [12]. Several studies have reported an increased spread of KPC-producing K. pneumoniae such as the recent study conducted in Italy where $50 \%$ of carbapenem-resistant isolates were KPC-2 producers [15]. Moreover, OXA-48 carbapenemase is the main carbapenemase found in Turkey, Malta, and the Middle East [12]. Following its initial description in Turkey, OXA-48 carbapenemase has been reported in different parts of the world, mainly in the Mediterranean basin where several studies have described the emergence and spread of OXA-48 producing bacteria in that region [16].

Moreover, the emergence of MDR and extensively-drug-resistant (XDR) Gram-negative bacteria, as well as the lack of new agents against these pathogens, led to the reintroduction of colistin [17]. The use of colistin had been abandoned many years ago due to concerns about nephrotoxicity, however it is now regarded as a last resort option in infections caused by MDR bacteria [11,18-20]. The mechanisms of colistin resistance are complex and varied and can range from chromosomal to plasmidic. In addition, there is also a type of adaptive resistance that is simply related to the modification of lipopolysaccharides (LPS) moiety that changes the charge of the molecule, thus preventing binding [21-23].

The population of Lebanon was estimated to be 3,759,136 in 2007. This number increased to $4,822,000$ in 2013 , of which $21 \%$ were under 15 years of age and $12 \%$ over 60 years of age [24].

This dramatic increase is partly attributed to the influx of Syrian refugees following the declaration of war in Syria in 2012, which caused a large budget deficit exacerbated by the withdrawal of international organisations that had promised to participate in funding [25]. Many Syrian refugees currently in Lebanon live in poor living conditions with limited access to healthcare, clean water, and inadequate food [26,27].There is no reliable health-related database to promote better care for this underserved population. More importantly, there is little data available concerning the epidemiology of antimicrobial resistance in the Syrian refugee population. The gastrointestinal tract is known to be a reservoir of Gram negative Enterobacteriaceae, and it has been shown that colonisation by MDR Enterobacteriaceae increase by at least two-fold the risk of subsequent infection [28]. Given that this may cause barriers to primary health care, we attempted to look at the prevalence of antimicrobial resistance, in particular carbapenem and colistin resistance genes which were isolated from bacteria, particularly Enterobacteriaceae, among Syrian refugees in North Lebanon, who live in unhygienic conditions, have limited toilet facilities, consume polluted water, very poor food quality, and live in overcrowded environments.

\section{Materials and Methods}

\subsection{Study Design}

Between June and July 2019, 250 rectal swabs were collected from the inhabitants of two Syrian refugee camps, located in North Lebanon, in the Akkar Governorate (Figure 1). One hundred random samples were collected from the Talhayat camp and another 150 from 
the Bebnine camp. The swabs were grouped according to whether they came from residents of the same tent and/or family. The swabs were inserted through the rectal sphincter $1-1.5$ inches $(2-3 \mathrm{~cm})$ and rotated gently. Tubes containing the swabs were placed in a refrigerator $\left(2-8{ }^{\circ} \mathrm{C}\right)$, after checking that faecal material was visible on the tip of the swab. The swabs were directly shipped to the laboratory (less than $1.5 \mathrm{~h}$ away) where they were directly cultivated on Tryptic soy broth (TSB) medium (Becton Dickinson GmbH, Heidelberg, Germany).

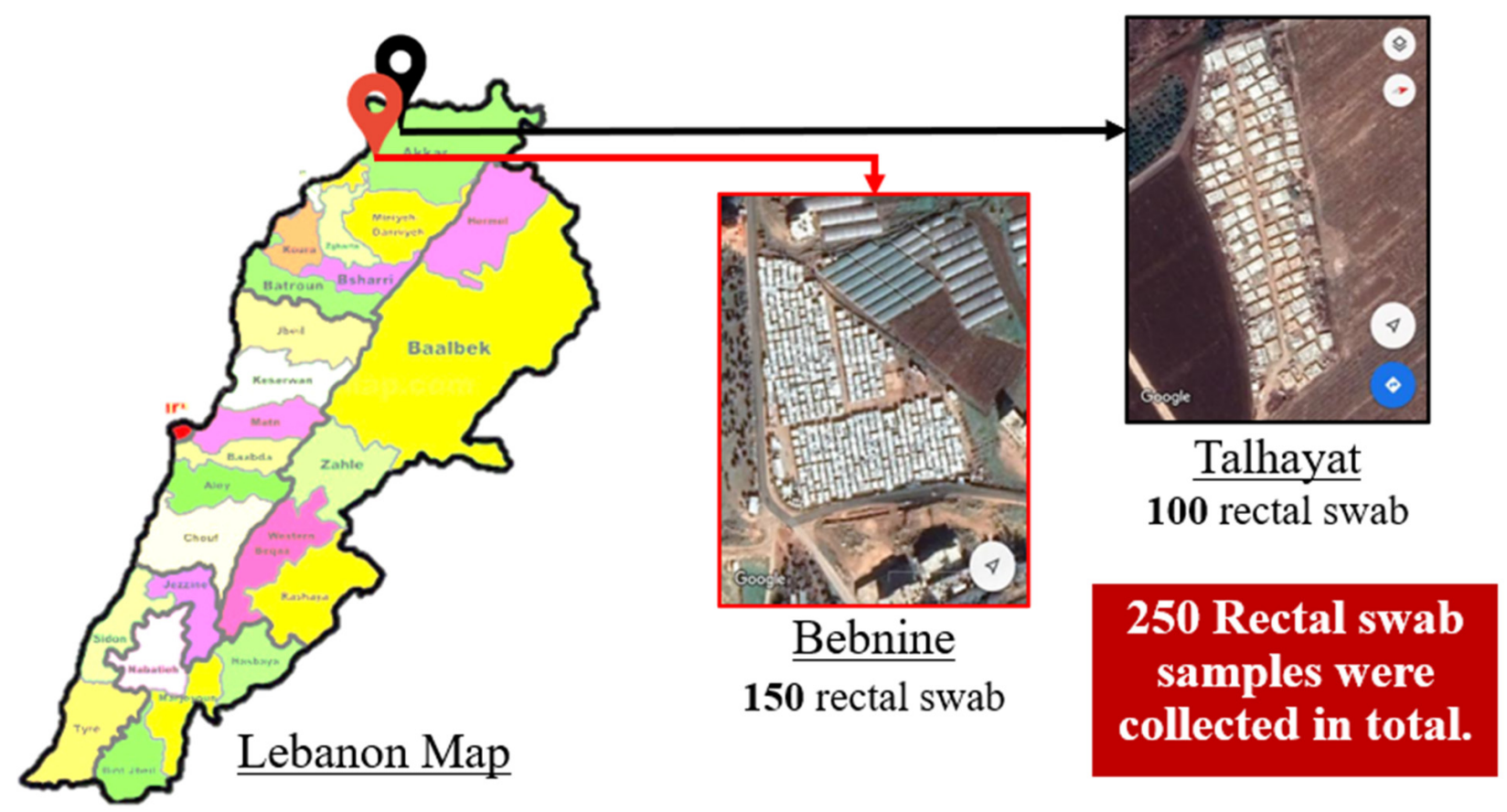

Figure 1. The location of the two camps in Lebanon where samples were taken.

\subsection{Bacterial Identification}

The rectal swabs were cultivated in the growth medium Tryptic soy broth (TSB) (Becton Dickinson $\mathrm{GmbH}$, Heidelberg, Germany) and incubated for $24 \mathrm{~h}$ at $37^{\circ} \mathrm{C}$. Different selective media, including Lucie Bardet Jean-Marc Rolain (LBJMR) [29] and MacConkey agar (bioMérieux, Marcy l'Etoile, France) supplemented with Ertapenem $(2 \mu \mathrm{g} / \mathrm{mL})$ were then used to culture $100 \mu \mathrm{L}$ of the enrichment medium. These media were used to screen colistin resistant and carbapenem resistant organisms, respectively. The selected isolates were then sent to the laboratory in Marseille, France. Bacterial identification at the species level was performed using matrix-assisted laser desorption/ionization time-of-flight mass spectrometry (MALDI-TOF) (Microflex; Bruker Daltonics).

\subsection{Antibiotic Susceptibility Profile}

The antibiotic susceptibility profile of the isolates was identified using the standard disk diffusion method on Mueller-Hinton agar (bioMérieux, Marcy l'Etoile, France). Sixteen different antibiotics were tested, including amoxicillin $(20 \mu \mathrm{g})$, amoxicillin-clavulanic acid $(20 / 10 \mu \mathrm{g})$, piperacillin-tazobactam $(30 / 6 \mu \mathrm{g})$, cephalotin $(30 \mu \mathrm{g})$, ceftriaxone $(30 \mu \mathrm{g})$, cefepime $(30 \mu \mathrm{g})$, ertapenem $(10 \mu \mathrm{g})$, imipenem $(10 \mu \mathrm{g})$, amikacin $(30 \mu \mathrm{g})$, gentamicin $(10 \mu \mathrm{g})$, ciprofloxacin $(5 \mu \mathrm{g})$, Fosfomycin $(200 \mu \mathrm{g})$, nitrofurantoin $(100 \mu \mathrm{g})$, tobramycin $(10 \mu \mathrm{g})$, trimethoprim-sulfamethoxazole $(1.25 / 23.75 \mu \mathrm{g})$, and colistin $(10 \mu \mathrm{g})$ (bioMérieux, Marcy l'Etoile, France). The minimal inhibitory concentration (MIC) of colistin, ertapenem, and imipenem was identified using the microdilution and the E-test methods, respectively. Each strain was considered to be resistant to colistin, ertapenem, and imipenem if their 
MICs were greater than $2 \mathrm{mg} / \mathrm{L}, 1 \mathrm{mg} / \mathrm{L}$, and $8 \mathrm{mg} / \mathrm{L}$, respectively. The results were interpreted according to the European Microbial Medical Sensitivity Committee (EUCAST) 2017 (http:/ / www.Sfmicrobiology.Org/Userfiles/Files/Files/CASFM/CASF\%20V2_0_MAI201 7.PDF, accessed on 25 September 2020).

\subsection{Phenotypic Detection of Carbapenemase Activity}

Three phenotypic tests, the modified Hodge test (MHT), the modified Carba NP test (MCNP), and the ethylene diamine tetra-acetic acid (EDTA) test, were performed to detect the production of carbapenemase, as described previously [30,31].

\subsection{DNA Extraction}

The extraction of the bacterial DNA was performed by the EZ1-automatic robot (Qiagen Biorobot EZ1-, Tokyo, Japan) using an extraction kit (DNA EZ1, Qiagen, Hilden, Germany), following the manufacturer's instructions. The extracted DNA was kept at $-20{ }^{\circ} \mathrm{C}$. In order to determine the genetic location of the carbapenemase and $m c r$ genes, plasmid extraction was performed for the isolates that showed a positive PCR result for these genes using the GeneJET Plasmid Miniprep Kit (Thermo Fisher Scientific, Waltham, MA, USA).

\subsection{Molecular Identification of Carbapenem and Colistin Resistance Genes}

The presence of carbapenemase encoding genes such as $b l a_{\mathrm{OXA}-48}, b l a_{\mathrm{OXA}-58}, b l a_{\mathrm{KPC}}$, $b l a_{\mathrm{NDM}}$, and bla $a_{\mathrm{VIM}}$ was investigated by the real-time PCR assay (RT-PCR) (Bio-Rad, CFX96 Touch ${ }^{\mathrm{TM}}$, Hercules, CA, USA) using specific primers, as previously described [32,33]. Moreover, RT-PCR for colistin resistant isolates was performed to detect the presence of $m c r-1, m c r-2, m c r-3, m c r-4, m c r-5$, and $m c r-8$ genes using previously described primers and probes $[34,35]$.

Standard PCR and sequencing of antibiotic resistance genes was performed on an automated ABI 3130 sequencer (PE Applied Biosystems, Foster City, CA, USA) using BigDye terminator chemistry. The sequenced genes were analysed using BlastN and BlastP and then compared with the ARG-ANNOT database.

All mcr-negative colistin-resistant bacteria were investigated for the presence of possible mutations in colistin-resistance genes such as $\operatorname{pmr} A, \operatorname{pmr} B, p h o P$, phoQ, and $m g r B$ by amplification and sequencing $[32,36,37]$. Those genes were compared with reference strains such as E. coli K-12 MG 1655 (NCBI GenBank accession no. U00096.3), K. pneumoniae MGH 78578 (NCBI GenBank accession no. CP000647), and E. cloacae ATCC 13047 (NCBI GenBank accession no. CP001918.1) using nps alignment software (https:/ / prabi.ibcp.fr/ $\mathrm{htm}$ / site/web/home, accessed on 18 February 2021).

In order to determine whether the recognised amino acid substitution resulting from a missense mutation could affect the function of the protein, PROVEAN (Protein Variation Effect Analyser) software (http:/ / provean.jcvi.org/seq_submit.php, accessed on 18 February 2021) was used. If the score of the variant proteins was below or equal to a predefined threshold (-2.5), it was considered to have a "deleterious" effect, and if the score was above the threshold, it was predicted to have a "neutral" effect.

\subsection{Multilocus Sequence Typing (MLST)}

In order to determine the clonal relationship of the isolates, the MLST method was performed as described on the Institute Pasteur's MLST website (www.pasteur.fr/mlst, accessed on 23 March 2021).

\section{Results}

From 250 rectal swabs, 25 carbapenem and/or colistin resistant strains were isolated $(10 \%)$. Among the isolates, 16 carbapenem-resistant strains were identified, namely, seven Klebsiella pneumoniae, six Escherichia coli, and three Enterobacter cloacae. Moreover, five $E$. coli isolates were resistant to colistin. The remaining four isolates were identified as 
K. pneumoniae and were resistant to carbapenem and colistin. The antibiotic resistance profile is presented in Table 1 for carbapenem-resistant (CarbaR) strains and in Table 2 for colistinresistant (ColiR) strains. Imipenem MICs ranged from 2 to $>32 \mathrm{mg} / \mathrm{L}$ (Tables 1 and 2) and ertapenem MICs ranged from 4 to $>32 \mathrm{mg} / \mathrm{L}$ (Tables 1 and 2). In contrast, according to the Unitary Minimum Inhibitory Concentration (UMIC) test, colistin MICs for K. pneumoniae and $E$. coli isolates were $>64 \mathrm{mg} / \mathrm{L}$ and $4 \mathrm{mg} / \mathrm{L}$, respectively (Table 2). The MCNP test and the MHT were positive for all carbapenem-resistant isolates, whereas the EDTA test was positive for all carbapenem-resistant isolates except for KP-2, KP-3, KP-4, and KP-5 isolates. Real-time PCR and standard PCR results showed that E. coli CarbaR (EC-1, EC-2, EC-3, EC-4, EC-5, and EC-6), E. cloacae CarbaR (Eclo-1, Eclo-2, and Eclo-3), and K. pneumoniae ColiR (KP-1, KP-2, KP-3, and KP-4) were positive for bla $a_{\mathrm{NDM}}$ gene. Sequence analysis of detected carbapenemases identified the $b l a_{\mathrm{NDM}-1}$ gene in positive strains (Tables 1 and 2). In contrast, results showed that K. pneumoniae CarbaR (KP-2, KP-3, KP-4, KP-5, KP-6, KP-7, and $\mathrm{KP}-8$ ) were positive for the $b l a_{\mathrm{OXA}}$ gene. Sequence analysis of detected carbapenemases identified the $b a_{\mathrm{OXA}-48}$ gene in positive strains (Table 1). Moreover, results showed that K. pneumoniae CarbaR strains (KP-6, KP-7, and KP-8) harboured, in addition, the $b l a_{\mathrm{NDM}}$ gene. Sequence analysis of detected carbapenemases identified the $b l a_{\mathrm{NDM}-1}$ gene in positive strains (Table 1). In addition, results showed that E. coli coliR (EC-7, EC-8, EC-9, EC-10, and EC-11) were positive for the $m c r-1$ gene and were identified as the $m c r-1$ gene by sequencing (Table 2 ).

Table 1. Phenotypic and genotypic features of the carbapenem-resistant Enterobacteriaceae isolates.

\begin{tabular}{|c|c|c|c|c|c|c|c|c|c|c|c|}
\hline & Strain Name & Source & $\begin{array}{l}\text { Antibiotic } \\
\text { Susceptibility } \\
\text { Profile }\end{array}$ & $\begin{array}{l}\text { MAR } \\
\text { Index }\end{array}$ & $\begin{array}{c}\text { IMP } \\
\text { MIC } \\
(\mu \mathrm{g} / \mathrm{mL})\end{array}$ & $\begin{array}{c}\text { ERT } \\
\text { MIC } \\
(\mu \mathrm{g} / \mathrm{mL})\end{array}$ & $\begin{array}{l}\text { Carba } \\
\text { NP } \\
\text { Test }\end{array}$ & $b l a_{\mathrm{OXA}-48}$ & $b l a_{\mathrm{NDM}-1}$ & ST & $\begin{array}{c}\text { Accession } \\
\text { Number }\end{array}$ \\
\hline \multirow{5}{*}{$\begin{array}{l}\text { Same } \\
\text { tent } \\
\text { (same } \\
\text { family) }\end{array}$} & E. coli EC-1 & $\mathrm{BN}$ & $\begin{array}{c}\mathrm{FF}, \mathrm{F}, \mathrm{AK}, \mathrm{CS}, \\
\mathrm{CN}\end{array}$ & 0.68 & 12 & $>32$ & + & - & + & 361 & OL542491 \\
\hline & E. coli EC-2 & $\mathrm{BN}$ & $\begin{array}{c}\mathrm{FF}, \mathrm{F}, \mathrm{AK}, \mathrm{CS}, \\
\mathrm{CN}\end{array}$ & 0.68 & $>32$ & $>32$ & + & - & + & 361 & OL542492 \\
\hline & E. coli EC-3 & $\mathrm{BN}$ & $\begin{array}{c}\mathrm{FF}, \mathrm{F}, \mathrm{AK}, \mathrm{CS}, \\
\mathrm{CN}\end{array}$ & 0.68 & 16 & $>32$ & + & - & + & 361 & OL542493 \\
\hline & E. coli EC-4 & $\mathrm{BN}$ & $\begin{array}{c}\mathrm{FF}, \mathrm{F}, \mathrm{AK}, \mathrm{CS}, \\
\mathrm{CN}\end{array}$ & 0.68 & $>32$ & $>32$ & + & - & + & 1294 & OL542494 \\
\hline & E. coli EC-5 & $\mathrm{BN}$ & $\begin{array}{c}\mathrm{FF}, \mathrm{F}, \mathrm{AK}, \mathrm{CS}, \\
\mathrm{CN}\end{array}$ & 0.68 & $>32$ & $>32$ & + & - & + & 1294 & OL542495 \\
\hline \multirow{4}{*}{$\begin{array}{l}\text { Same } \\
\text { tent } \\
\text { (same } \\
\text { family) }\end{array}$} & E. coli EC-6 & $\mathrm{TL}$ & $\begin{array}{c}\mathrm{FF}, \mathrm{F}, \mathrm{AK}, \mathrm{CS}, \\
\mathrm{CN}\end{array}$ & 0.68 & 4 & $>32$ & + & - & + & 648 & OL542496 \\
\hline & $\begin{array}{l}\text { E. cloacae } \\
\text { Eclo-1 }\end{array}$ & $\mathrm{BN}$ & $\mathrm{DO}, \mathrm{CS}$ & 0.87 & 4 & 12 & + & - & + & 182 & OL474360 \\
\hline & $\begin{array}{l}\text { E. cloacae } \\
\text { Eclo-2 }\end{array}$ & $\mathrm{BN}$ & CS & 0.93 & 4 & 8 & + & - & + & 182 & OL474361 \\
\hline & $\begin{array}{l}\text { E. cloacae } \\
\text { Eclo-3 }\end{array}$ & $\mathrm{TL}$ & CS & 0.93 & 4 & 8 & + & - & + & 1120 & OL474362 \\
\hline \multirow{4}{*}{$\begin{array}{l}\text { Tents are } \\
\text { close } \\
\text { (Not the } \\
\text { same } \\
\text { family) }\end{array}$} & $\begin{array}{l}\text { K. pneumoniae } \\
\text { KP-2 }\end{array}$ & $\mathrm{BN}$ & $\mathrm{AK}, \mathrm{CS}, \mathrm{CN}$ & 0.81 & $>32$ & $>32$ & + & + & - & 16 & OL542509 \\
\hline & $\begin{array}{l}\text { K. pneumoniae } \\
\text { KP-3 }\end{array}$ & $\mathrm{BN}$ & $\mathrm{AK}, \mathrm{CS}, \mathrm{CN}$ & 0.81 & $>32$ & $>32$ & + & + & - & 16 & OL542510 \\
\hline & $\begin{array}{c}\text { K. pneumoniae } \\
\text { KP-4 }\end{array}$ & $\mathrm{BN}$ & TZP, CS & 0.87 & $>32$ & $>32$ & + & + & - & 16 & OL542511 \\
\hline & $\begin{array}{c}\text { K. pneumoniae } \\
\text { KP-5 }\end{array}$ & $\mathrm{BN}$ & $\mathrm{AK}, \mathrm{CS}, \mathrm{CN}$ & 0.81 & $>32$ & $>32$ & + & + & - & 16 & OL542512 \\
\hline \multirow{3}{*}{$\begin{array}{l}\text { Tents are } \\
\text { close } \\
\text { (Not the } \\
\text { same } \\
\text { family) }\end{array}$} & $\begin{array}{l}\text { K. pneumoniae } \\
\text { KP-6 }\end{array}$ & $\mathrm{TL}$ & $\mathrm{DO}, \mathrm{CS}$ & 0.87 & $>32$ & $>32$ & + & + & + & 14 & $\begin{array}{l}\text { OL542513 } \\
\text { OL542506 }\end{array}$ \\
\hline & $\begin{array}{c}\text { K. pneumoniae } \\
\text { KP-7 }\end{array}$ & $\mathrm{TL}$ & $\mathrm{AK}, \mathrm{DO}, \mathrm{CS}$ & 0.81 & $>32$ & $>32$ & + & + & + & 14 & $\begin{array}{l}\text { OL542514 } \\
\text { OL542507 }\end{array}$ \\
\hline & $\begin{array}{l}\text { K. pneumoniae } \\
\text { KP-8 }\end{array}$ & $\mathrm{TL}$ & $\mathrm{FF}, \mathrm{AK}, \mathrm{DO}, \mathrm{CS}$ & 0.75 & $>32$ & $>32$ & + & + & + & 14 & $\begin{array}{l}\text { OL542515 } \\
\text { OL542508 }\end{array}$ \\
\hline
\end{tabular}

Fosfomycin (FF), nitrofurantoin (F), amikacin (AK), doxycycline (DO), colistin (CS), piperacillin-tazobactam (TZP), cefalotin (CF), gentamicin (CN), ertapenem (ERT), imipenem (IMP), minimum inhibitory concentration (MIC), sequence type (ST), multiple antibiotic resistance (MAR), Talhayat (TL), and Bebnine (BN). 
Table 2. Phenotypic and genotypic features of the colistin and carbapenem-resistant Enterobacteriaceae isolates.

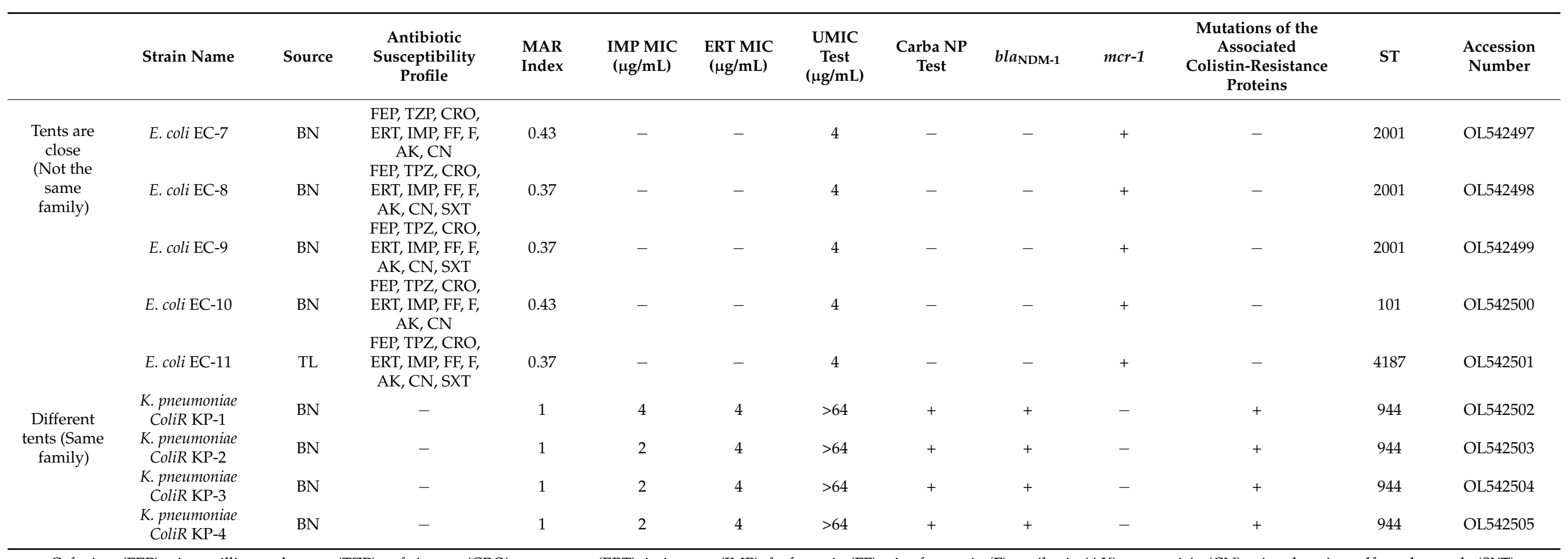

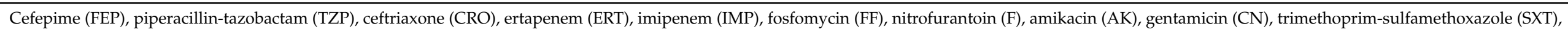
doxycycline (DO), colistin (CS), minimum inhibitory concentration (MIC), sequence type (ST), multiple antibiotic resistance (MAR), Talhayat (TL), and Bebnine (BN). 
Moreover, PCRs performed on extracted plasmids (from isolates that had a positive PCR for carbapenemase and $m c r-1$ genes), showed a positive result for these genes assuming a plasmidic localisation.

Due to the absence of mor genes in K. pneumoniae ColiR (Table 2), genes implicated in colistin resistance $(m g r B, p m r A, p m r B, p h o P$, and $p h o Q)$ were amplified and sequenced. As shown in Table 3, the result of the sequence analysis showed that there was no mutation in the $m g r b, p m r A$, and $p h o P$ genes for the four colistin-resistant K. pneumoniae isolates. These isolates were resistant to colistin due to mutations in the $p m r B$ and $p h o Q$ genes (Table 3). For the colistin resistant $\mathrm{Kp}-1$ isolate, the analysis revealed a nucleotide deletion (C577del) in the $p m r B$ gene, leading to a frameshift mutation and resulting in a defective protein. For the colistin resistant Kp-2, the analysis revealed a nucleotide insertion (G432_C433insG) in the $\mathrm{pmrB}$ gene, causing a frameshift mutation and resulting in a defective protein. For the $\mathrm{Kp}-3$ isolate, the analysis also revealed a nucleotide insertion at position (T459_G460insC) in the $p h o Q$ gene leading to a frameshift mutation and resulting in a defective protein. Finally, for the Kp-4 isolate, the analysis showed two genetic modifications: a nucleotide insertion (G623_C624insG) in the pmrB gene leading to a frameshift mutation resulting in a defective protein, and a nucleotide insertion at position (T435_A436insT) in the phoQ gene causing a frameshift mutation resulting in a defective protein.

Table 3. Results of the nucleotide mutations of the colistin-resistant strains.

\begin{tabular}{|c|c|c|c|c|c|c|}
\hline Strain Name & Mgrb & PmrA & PmrB & PhoP & PhoQ & Accession Number \\
\hline Coli R Kp 1 & No mutation & No mutation & C577del & No mutation & No mutation & OL587685 \\
\hline Coli R Kp 2 & No mutation & No mutation & G432_C433insG & No mutation & No mutation & OL587686 \\
\hline Coli R Kp 3 & No mutation & No mutation & No mutation & No mutation & T459_G460insC & OL587683 \\
\hline Coli R Kp 4 & No mutation & No mutation & G623_C624insG & No mutation & T435_A436insT & $\begin{array}{l}\text { OL587687 } \\
\text { OL587684 }\end{array}$ \\
\hline
\end{tabular}

MLST analysis revealed that nine E. coli isolates belonged to six different sequence types (STs) including ST361 (E. coli carbaR: EC-1, EC-2, EC-3), ST1294 (E. coli carbaR: EC-4, EC-5), ST648 (E. coli CarbaR: EC-6) (Table 1), ST2001 (E. coli ColiR: EC-7, EC-8, EC-9), ST101 (E. coli ColiR: EC-10), and ST4187 (E. coli ColiR: EC-11). K. pneumoniae isolates had several STs such as ST14 (K. pneumoniae CarbaR: KP-2, KP-3, KP-4, Kp-5), ST16 (K. pneumoniae CarbaR: KP-6, KP-7, KP-8) (Table 1), and ST944 (KP-1, KP-2, KP-3, KP-4) (Table 2), and the tree E. cloacae belonged to ST182 (Eclo-1, Eclo-2) and ST1120 (Eclo-3) (Table 1).

\section{Discussion and Conclusions}

MDR bacteria are now considered as a serious public health problem due to the limited range of antibiotics used to treat infections caused by these bacteria. The antimicrobial resistance crisis is mainly due to the misuse of these antibiotics in several sectors (human and animal) and the luck of discovery of new drugs [38]. Refugees coming from countries with a high occurrence of antimicrobial resistance can introduce the resistant isolates to their new country of residence. These refugees can spread these resistant bacteria, especially if they are living in shelters with poor living conditions. This study describes the intestinal carriage of carbapenem- and colistin-resistant bacteria particularly in Enterobacteriaceae among healthy Syrian refugees living in two shelters (Bebnine and Talhayat) in North Lebanon.

In this study, 25 carbapenem- and/or colistin-resistant isolates were collected from 250 rectal swabs isolated from healthy Syrian refugees. All isolates were resistant to the majority of antibiotics tested. PCR and sequencing showed the presence of 16 carbapenemresistant isolates (6 E. coli, $7 \mathrm{~K}$. pneumoniae, and 3 E. cloacae), 5 colistin-resistant isolates (E. coli), and 4 carbapenem and colistin-resistant isolates (K. pneumoniae) (Tables 1 and 2).

All carbapenem-resistant $E$. coli isolates (six isolates) harboured the $b l a_{\mathrm{NDM}-1}$ gene. Five of them (EC-1, EC-2, EC-3, EC-4, and EC-5) were collected from the same shelter (Bebnine), and from the same tent; three isolates (EC-1, EC-2, and EC-3) belonged to ST361 and two (EC-4 and EC-5) belonged to ST1294. The bla $a_{\mathrm{NDM}-1}$ E. coli ST361 had already 
been reported in hospitalised patients in South Korea [39]; however, ST1294 is mainly found in animals and in the environment [40-45]. These results shed light on the clonal dissemination of these isolates between refugees, since the same clones were found in more than one person in the same tent, but also to the probable zoonotic or environmental origin of the ST1294 isolates. The sixth isolate (EC-6) belonged to ST648 and was collected from the Talhayat shelter. This clone was previously reported in different studies in hospitalised patients [46-48]. In Lebanon, NDM-1 producing E. coli isolates were first described in 2012 in Iraqi patients referred to Lebanon [49]. Moreover, NDM-1 producing E. coli was also reported in 2013 at a tertiary care centre in Lebanon [50]. To the best of our knowledge, this is the first report of intestinal carriage of NDM-1 producing E. coli in healthy individuals.

All carbapenem-resistant K. pneumoniae isolates (seven isolates: KP-2, KP-3, KP-4, KP-5, KP-6, KP-7, and KP-8) harboured the bla OXA-48 gene, of which three also had the $b l a_{\mathrm{NDM}-1}$ gene (KP-6, KP-7, and KP-8). The carbapenem-resistant $K$. pneumoniae isolates (KP-2, KP-3, KP-4, and KP-5) harbouring the OXA-48 gene had the same ST (ST16) and were collected from the same shelter (Bebnine) and from closely related tents. OXA48 producing K. pneumoniae ST16 was previously described in clinical isolates in Spain [51]. In Lebanon, several studies have reported the occurrence of OXA-48 producing bacteria and OXA-48 producing K. pneumoniae, all from hospital settings [49,52-54]. In addition, the remaining three isolates (KP-6, KP-7, and KP-8) harbouring both the NDM-1 and the OXA-48 genes, also had the same ST (ST14), and were collected from the Talhayat shelter from closely related tents. NDM- 1 and/or OXA-48 producing K. pneumoniae ST14 have been reported worldwide [55-58], highlighting the rapid spread of this clone. In Lebanon, several studies have described NDM-1 and/or OXA-48 producing K. pneumoniae isolates [49,52,53]; however, this is the first description of the co-occurrence of NDM-1 and OXA-48 genes in the same isolate, which highlights the dissemination of plasmids carrying these resistance genes between isolates. Furthermore, results showed that K. pneumoniae isolates recovered from closely related tents in the same shelter belonged to the same clone. Syrian refugees in Lebanon live in inadequate shelters living in crowded conditions with poor sanitary facilities, which increases the spread of resistant bacteria. This explains the dissemination of the same clone in refugees living in closely related tents within the same shelter.

All carbapenem-resistant E. cloacae isolates (Eclo-1, Eclo-2, Eclo-3) harboured the $b l a_{\text {NDM-1 }}$ gene, of which two (Eclo-1 and Eclo-2) were isolated from the same tent at the Bebnine shelter and belonged to the same clone (ST182). The remaining isolate belonged to ST1120 and was isolated from the Talhayat shelter. NDM-1 producing E. cloacae ST182 have been reported in many countries, including China, Czech Republic, and Kenya [59,60]. This clone is of high concern because of its ability to disseminate rapidly, causing outbreaks as was the case in Mexico [61]. Hence, controls should be performed to avoid the rapid dissemination of such clones. To the best of our knowledge, this is the first detection of NDM-1 producing E. cloacae in Lebanon.

In total, nine colistin-resistant isolates were collected, five E. coli (EC-7, EC-8, EC-9, EC-10, and EC-11) and four K. pneumoniae (ColiR KP-1, ColiR KP-2, ColiR KP-3, and ColiR KP-4).

All colistin-resistant E. coli isolates harboured the $m c r-1$ gene, of which three (EC-7, EC-8, EC-9) belonged to the same clone ST2001 and were isolated from closely related tents at the Bebnine shelter. The remaining E. coli isolates belonged to ST101 (Bebnine shelter) and ST4187 (Talhayat shelter). E. coli ST2001 has been previously described in feacal samples from wild animals [62] and in an organic broiler farm [63]. ST4187 has been described in broiler chickens in Tunisia [64], thus pointing towards a zoonotic origin of our isolates, since the refugees are in close contact with wild animals. The ST101 clone has been reported in clinical samples from Brazil and Iran $[65,66]$. In Lebanon, E. coli harbouring the $m c r-1$ gene has been described in few studies in hospitalised patients [67], however, no other study has highlighted its presence in healthy individuals. To the best of our knowledge, this is the first description in Lebanon of the intestinal carriage of 
E. coli isolates harbouring the $m c r-1$ gene in healthy individuals. This is alarming, since the plasmid carrying the $m c r-1$ gene could disseminate between species, making them resistant to one of our last resort antibiotics.

All colistin-resistant K. pneumoniae isolates harboured the bla $a_{\mathrm{NDM}-1}$ gene and had mutations in the PmrB and/or PhoQ genes (Table 3). They were all isolated from the same family (in the Bebnine camp) and belonged to the same clone ST944. An ST944 clone harbouring the $m c r-1$ gene has been previously described in chicken meat from western Algeria [68]. A recent study conducted in Egypt [69] described colistin and carbapenem resistance in K. pneumoniae strains isolated from chicken and humans. The study showed that all K. pneumoniae were MDR, with $45.9 \%$ harbouring a $ß$-lactamase gene with a carbapenemase gene, $18.9 \%$ harbouring a $B$-lactamase gene with the $m c r-1$ gene, and $13.5 \%$ harbouring a $\beta$-lactamase gene with both carbapenemase and $m c r-1$ genes. In Lebanon, few studies have described colistin-resistance in K. pneumoniae isolates such as those in 2015 [70] and 2017 [71]. Our study showed new mutations (Table 3) in the $p m r B$ and/or $p h o Q$ genes resulting in a defective protein with a stop codon. Interestingly, $a$ study conducted in Lebanon in 2018 [72] described colistin-resistance in clinical K. pneumoniae isolates due to mutations in the $m g r B, p m r B$, and $p h o Q$ genes. These isolates also harboured the $b l a_{\mathrm{NDM}-5}$ gene. Our study reported for the first time in Lebanon, colistin-resistance K. pneumoniae isolates with new mutations in $p m r B$ and/or $p h o Q$ genes and harbouring the $b l a_{\mathrm{NDM}-1}$ gene.

In conclusion, the intestinal carriage of MDR bacteria in community settings is of great concern. Our study reported for the first time the intestinal carriage of carbapenemand/or colistin-resistant isolates in refugees, which is alarming since plasmids carrying resistance genes can spread between bacteria and refugees within the same shelter. Syrian refugees come from a country with a high prevalence of antimicrobial resistance where antibiotics can be taken without prescription, thus they can spread MDR bacteria to their final destination, in this case, Lebanon. In addition, these refugees are living in inadequate shelters which can contribute to the spread of these bacteria. Molecular and epidemiological studies are essential in order to better understand the mode of transmission of these microorganisms. An urgent strategy must therefore be adopted to limit the spread of these MDR bacteria within the community.

Author Contributions: Conceptualisation, C.A.-B.; data curation, C.A.-B., A.A., T.N.D., F.F. and M.F.; formal analysis, C.A.-B., A.A. and T.N.D.; funding acquisition, J.-M.R.; investigation, C.A.-B., A.A. and T.N.D.; methodology, C.A.-B., A.A., T.N.D., F.F. and M.F.; project administration, C.A.-B. and J.-M.R.; resources, C.A.-B. and J.-M.R.; supervision, C.A.-B. and J.-M.R.; validation, C.A.-B. and J.-M.R.; visualisation, C.A.-B., A.A. and T.N.D.; writing-original draft, C.A.-B., A.A. and T.N.D.; writing-review and editing, C.A.-B., A.A., T.N.D. and J.-M.R. All authors have read and agreed to the published version of the manuscript.

Funding: This work was supported by the Lebanese University, in collaboration with the French Government under the "Investissements d'avenir" programme (Investments for the Future) managed by the Agence Nationale de la Recherche (ANR, fr: National Agency for Research), (reference: Méditerranée Infection 10-IAHU-03).

Institutional Review Board Statement: This study was approved by the Saydet Zgharta University Medical Center ethical committee, Code MA-LE-E-08/2019, Date: 16 May 2019.

Informed Consent Statement: Not applicable.

Data Availability Statement: The data presented in this study are available in Tables 1 and 2.

Acknowledgments: We thank Linda Hadjadj and Sophie Baron for technical assistance.

Conflicts of Interest: No conflicts of interest or financial disclosure for all authors. 


\section{References}

1. Marshall, B.M.; Levy, S.B. Food Animals and Antimicrobials: Impacts on Human Health. Clin. Microbiol. Rev. 2011, 24, 718-733. [CrossRef] [PubMed]

2. Singer, A.C.; Shaw, H.; Rhodes, V.; Hart, A. Review of Antimicrobial Resistance in the Environment and Its Relevance to Environmental Regulators. Front. Microbiol. 2016, 7, 1728. [CrossRef]

3. Davies, J. Origins and Evolution of Antibiotic Resistance. Microbiología 1996, 12, 9-16. [CrossRef]

4. Kadri, S.S. Key Takeaways from the U.S. CDC's 2019 Antibiotic Resistance Threats Report for Frontline Providers. Crit. Care Med. 2020, 48, 939-945. [CrossRef]

5. WHO. Library Cataloguing-In-Publication Data Global Action Plan on Antimicrobial Resistance; WHO: Geneva, Switzerland, 2015; ISBN 9789241509763.

6. Mellouk, F.Z.; Bakour, S.; Meradji, S.; Al-Bayssari, C.; Bentakouk, M.C.; Zouyed, F.; Djahoudi, A.; Boutefnouchet, N.; Rolain, J.M. First Detection of VIM-4-Producing Pseudomonas Aeruginosa and OXA-48-Producing Klebsiella Pneumoniae in Northeastern (Annaba, Skikda) Algeria. Microb. Drug Resist. 2017, 23, 335-344. [CrossRef]

7. Carmeli, Y.; Akova, M.; Cornaglia, G.; Daikos, G.L.; Garau, J.; Harbarth, S.; Rossolini, G.M.; Souli, M.; Giamarellou, H. Controlling the Spread of Carbapenemase-Producing Gram-Negatives: Therapeutic Approach and Infection Control. Clin. Microbiol. Infect. 2010, 16, 102-111. [CrossRef]

8. Taggar, G.; Rheman, M.A.; Boerlin, P.; Diarra, M.S. Molecular Epidemiology of Carbapenemases in Enterobacteriales from Humans, Animals, Food and the Environment. Antibiotics 2020, 9, 693. [CrossRef] [PubMed]

9. Nordmann, P.; Naas, T.; Poirel, L. Global Spread of Carbapenemase Producing Enterobacteriaceae. Emerg. Infect. Dis. 2011, 17, 1791-1798. [CrossRef]

10. Souli, M.; Galani, I.; Giamarellou, H. Emergence of Extensively Drug-Resistant and Pandrug-Resistant Gram-Negative Bacilli in Europe. Euro Surveill. 2008, 13, 19045. [CrossRef] [PubMed]

11. Giamarellou, H.; Poulakou, G. Multidrug-Resistant Gram-Negative Infections What Are the Treatment Options? Drugs 2009, 69, 1879-1901. [CrossRef]

12. Tilahun, M.; Kassa, Y.; Gedefie, A.; Belete, M.A. Emerging Carbapenem-Resistant Enterobacteriaceae Infection, Its Epidemiology and Novel Treatment Options: A Review. Infect. Drug Resist. 2021, 14, 4363-4374. [CrossRef] [PubMed]

13. Karki, D.; Dhungel, B.; Bhandari, S.; Kunwar, A.; Joshi, P.R.; Shrestha, B.; Rijal, K.R.; Ghimire, P.; Banjara, M.R. Antibiotic Resistance and Detection of Plasmid Mediated Colistin Resistance Mcr-1 Gene among Escherichia Coli and Klebsiella Pneumoniae Isolated from Clinical Samples. Gut Pathog. 2021, 13, 45. [CrossRef] [PubMed]

14. Thapa, S.; Adhikari, N.; Shah, A.K.; Lamichhane, I.; Dhungel, B.; Shrestha, U.T.; Adhikari, B.; Banjara, M.R.; Ghimire, P.; Rijal, K.R. Detection of NDM-1 and VIM Genes in Carbapenem-Resistant Klebsiella Pneumoniae Isolates from a Tertiary Health-Care Center in Kathmandu, Nepal. Chemotherapy 2021, 66, 199-209. [CrossRef]

15. Magi, G.; Tontarelli, F.; Caucci, S.; di Sante, L.; Brenciani, A.; Morroni, G.; Giovanetti, E.; Menzo, S.; Mingoia, M. High Prevalence of Carbapenem-Resistant Klebsiella Pneumoniae ST307 Recovered from Fecal Samples in an Italian Hospital. Future Microbiol. 2021, 16, 703-711. [CrossRef] [PubMed]

16. Mairi, A.; Pantel, A.; Sotto, A.; Lavigne, J.P.; Touati, A. OXA-48-like Carbapenemases Producing Enterobacteriaceae in Different Niches. Eur. J. Clin. Microbiol. Infect. Dis. 2018, 37, 587-604. [CrossRef]

17. Jeannot, K.; Bolard, A.; Plésiat, P. Resistance to Polymyxins in Gram-Negative Organisms. Int. J. Antimicrob. Agents 2017, 49, 526-535. [CrossRef] [PubMed]

18. Falagas, M.E.; Kasiakou, S.K.; Saravolatz, L.D. Colistin: The Revival of Polymyxins for the Management of Multidrug-Resistant Gram-Negative Bacterial Infections. Clin. Infect. Dis. 2005, 40, 1333-1341. [CrossRef]

19. Ko, K.S.; Suh, J.Y.; Kwon, K.T.; Jung, S.I.; Park, K.H.; Kang, C.I.; Chung, D.R.; Peck, K.R.; Song, J.H. High Rates of Resistance to Colistin and Polymyxin B in Subgroups of Acinetobacter Baumannii Isolates from Korea. J. Antimicrob. Chemother. 2007, 60, 1163-1167. [CrossRef] [PubMed]

20. Suh, J.Y.; Son, J.S.; Chung, D.R.; Peck, K.R.; Ko, K.S.; Song, J.H. Nonclonal Emergence of Colistin-Resistant Klebsiella Pneumoniae Isolates from Blood Samples in South Korea. Antimicrob. Agents Chemother. 2010, 54, 560-562. [CrossRef]

21. Baron, S.; Hadjadj, L.; Rolain, J.M.; Olaitan, A.O. Molecular Mechanisms of Polymyxin Resistance: Knowns and Unknowns. Int. J. Antimicrob. Agents 2016, 48, 583-591. [CrossRef]

22. Olaitan, A.O.; Morand, S.; Rolain, J.M. Mechanisms of Polymyxin Resistance: Acquired and Intrinsic Resistance in Bacteria. Front. Microbiol. 2014, 5, 643. [CrossRef] [PubMed]

23. Skiada, A.; Markogiannakis, A.; Plachouras, D.; Daikos, G.L. Adaptive Resistance to Cationic Compounds in Pseudomonas Aeruginosa. Int. J. Antimicrob. Agents 2011, 37, 187-193. [CrossRef]

24. National Health Statistics Report in Lebanon in Collaboration with Saint Joseph University of Beirut (USJ), World Health Organisation (WHO) and Ministry Of Public Health in LEBANON. National Health Statistics Report in Lebanon-Edition; Ministry Of Public Health in LEBANON: Baabda, Lebanon, 2012.

25. Saleh, S.; Ammar, W.; Natafgi, N.; Mourad, Y.; Dimassi, H.; Harb, H. Association Entre La Pluralité Des Payeurs, Les Coûts, Les Revenus et La Rentabilité: Étude Transversale Dans Des Hôpitaux Libanais. East. Mediterr. Health J. 2015, 21, 381-388. [CrossRef] 
26. Isenring, E.; Fehr, J.; Gültekin, N.; Schlagenhauf, P. Infectious Disease Profiles of Syrian and Eritrean Migrants Presenting in Europe: A Systematic Review. Travel Med. Infect. Dis. 2018, 25, 65-76. [CrossRef]

27. Abbara, A.; Rawson, T.M.; Karah, N.; El-Amin, W.; Hatcher, J.; Tajaldin, B.; Dar, O.; Dewachi, O.; Abu Sitta, G.; Uhlin, B.E.; et al. A Summary and Appraisal of Existing Evidence of Antimicrobial Resistance in the Syrian Conflict. Int. J. Infect. Dis. 2018, 75, 26-33. [CrossRef] [PubMed]

28. Ruppé, E.; Andremont, A. Causes, Consequences, and Perspectives in the Variations of Intestinal Density of Colonization of Multidrug-Resistant Enterobacteria. Front. Microbiol. 2013, 4, 129. [CrossRef]

29. Bardet, L.; le Page, S.; Leangapichart, T.; Rolain, J.M. LBJMR Medium: A New Polyvalent Culture Medium for Isolating and Selecting Vancomycin and Colistin-Resistant Bacteria. BMC Microbiol. 2017, 17, 220. [CrossRef] [PubMed]

30. Bakour, S.; Garcia, V.; Loucif, L.; Brunel, J.M.; Gharout-Sait, A.; Touati, A.; Rolain, J.M. Rapid Identification of CarbapenemaseProducing Enterobacteriaceae, Pseudomonas Aeruginosa and Acinetobacter Baumannii Using a Modified Carba NP Test. New Microbes New Infect. 2015, 7, 89-93. [CrossRef] [PubMed]

31. Yong, D.; Lee, K.; Yum, J.H.; Shin, H.B.; Rossolini, G.M.; Chong, Y. Imipenem-EDTA Disk Method for Differentiation of Metallo$\beta$-Lactamase-Producing Clinical Isolates of Pseudomonas Spp. and Acinetobacter Spp. J. Clin. Microbiol. 2002, 40, $3798-3801$. [CrossRef]

32. Christophy, R.; Osman, M.; Mallat, H.; Achkar, M.; Ziedeh, A.; Moukaddem, W.; Dabboussi, F.; Hamze, M. Prevalence, Antibiotic Susceptibility and Characterization of Antibiotic Resistant Genes among Carbapenem-Resistant Gram-Negative Bacilli and Yeast in Intestinal Flora of Cancer Patients in North Lebanon. J. Infect. Public Health 2017, 10, 716-720. [CrossRef]

33. Mesli, E.; Berrazeg, M.; Drissi, M.; Bekkhoucha, S.N.; Rolain, J.M. Prevalence of Carbapenemase-Encoding Genes Including New Delhi Metallo- $\beta$-Lactamase in Acinetobacter Species, Algeria. Int. J. Infect. Dis. 2013, 17, 739-743. [CrossRef]

34. Rebelo, A.R.; Bortolaia, V.; Kjeldgaard, J.S.; Pedersen, S.K.; Leekitcharoenphon, P.; Hansen, I.M.; Guerra, B.; Malorny, B.; Borowiak, M.; Hammerl, J.A.; et al. Multiplex PCR for Detection of Plasmid-Mediated Colistin Resistance Determinants, Mcr-1, Mcr-2, Mcr-3, Mcr-4 and Mcr-5 for Surveillance Purposes. Eurosurveillance 2018, 23. [CrossRef]

35. Nabti, L.Z.; Sahli, F.; Ngaiganam, E.P.; Radji, N.; Mezaghcha, W.; Lupande-Mwenebitu, D.; Baron, S.A.; Rolain, J.M.; Diene, S.M. Development of Real-Time PCR Assay Allowed Describing the First Clinical Klebsiella Pneumoniae Isolate Harboring Plasmid-Mediated Colistin Resistance Mcr-8 Gene in Algeria. J. Glob. Antimicrob. Resist. 2020, 20, 266-271. [CrossRef] [PubMed]

36. Jayol, A.; Poirel, L.; Dortet, L.; Nordmann, P. National Survey of Colistin Resistance Among-Producing Enterobacteriaceae and outbreak Caused by Colistin-Resistant OXA-48-Producing Pneumoniae, France, 2014. Eurosurveillance 2017, 22, 6-18. [CrossRef] [PubMed]

37. Olaitan, A.O.; Thongmalayvong, B.; Akkhavong, K.; Somphavong, S.; Paboriboune, P.; Khounsy, S.; Morand, S.; Rolain, J.-M. Clonal Transmission of a Colistinresistant Coli from a domesticated Pig to a Human in Laos. J. Antimicrob. Chemother. 2015, 70, 3404-3405.

38. Aslam, B.; Wang, W.; Arshad, M.I.; Khurshid, M.; Muzammil, S.; Rasool, M.H.; Nisar, M.A.; Alvi, R.F.; Aslam, M.A.; Qamar, M.U.; et al. Antibiotic Resistance: A Rundown of a Global Crisis. Infect. Drug Resist. 2018, 11, 1645-1658. [CrossRef] [PubMed]

39. Park, Y.; Choi, Q.; Kwon, G.C.; Koo, S.H. Emergence and Transmission of New Delhi Metallo-Beta-Lactamase-5-Producing Escherichia Coli Sequence Type 361 in a Tertiary Hospital in South Korea. J. Clin. Lab. Anal. 2020, 34, e23041. [CrossRef]

40. Kanamori, H.; Parobek, C.M.; Juliano, J.J.; Johnson, J.R.; Johnston, B.D.; Johnson, T.J.; Weber, D.J.; Rutala, W.A.; Anderson, D.J. Genomic Analysis of Multidrug-Resistant Escherichia Coli from North Carolina Community Hospitals: Ongoing Circulation of CTX-M-Producing ST131-H30Rx and ST131-H30R1 Strains. Antimicrob. Agents Chemother. 2017, 61, e00912-17. [CrossRef]

41. Meng, Q.; Bai, X.; Zhao, A.; Lan, R.; Du, H.; Wang, T.; Shi, C.; Yuan, X.; Bai, X.; Ji, S.; et al. Characterization of Shiga Toxin-Producing Escherichia Coli Isolated from Healthy Pigs in China. BMC Microbiol. 2014, 14, 5. [CrossRef] [PubMed]

42. Bleichenbacher, S.; Stevens, M.J.A.; Zurfluh, K.; Perreten, V.; Endimiani, A.; Stephan, R.; Nüesch-Inderbinen, M. Environmental Dissemination of Carbapenemase-Producing Enterobacteriaceae in Rivers in Switzerland. Environ. Pollut. 2020, $265,115081$. [CrossRef]

43. Dandachi, I.; Chabou, S.; Daoud, Z.; Rolain, J.M. Prevalence and Emergence of Extended-Spectrum Cephalosporin-, Carbapenemand Colistin-Resistant Gram Negative Bacteria of Animal Origin in the Mediterranean Basin. Front. Microbiol. 2018, 9, 2299. [CrossRef]

44. Scott, J.R.; Hinds, J.; Gould, K.A.; Millar, E.V.; Reid, R.; Santosham, M.; O’Brien, K.L.; Hanage, W.P. Nontypeable Pneumococcal Isolates among Navajo and White Mountain Apache Communities: Are These Really a Cause of Invasive Disease? J. Infect. Dis. 2012, 206, 73-80. [CrossRef] [PubMed]

45. Liu, X.; Liu, H.; Li, Y.; Hao, C. Association between Virulence Profile and Fluoroquinolone Resistance in Escherichia Coli Isolated from Dogs and Cats in China. J. Infect. Dev. Ctries. 2017, 11, 306-313. [CrossRef]

46. Zhang, L.P.; Xue, W.C.; Meng, D.Y. First Report of New Delhi Metallo- $\beta$-Lactamase 5 (NDM-5)-Producing Escherichia Coli from Blood Cultures of Three Leukemia Patients. Int. J. Infect. Dis. 2016, 42, 45-46. [CrossRef]

47. Patil, S.; Min, J.; Feiqiu, W. Molecular Characterization of Co-Existence of MCR-1 and NDM-1 in Extended-Spectrum $\beta$-LactamaseProducing Escherichia Coli ST648 Isolated from a Colonized Patient in China. Jundishapur J. Microbiol. 2019, 12, 91272. [CrossRef]

48. Mizuno, Y.; Yamaguchi, T.; Matsumoto, T. A First Case of New Delhi Metallo- $\beta$-Lactamase-7 in an Escherichia Coli ST648 Isolate in Japan. J. Infect. Chemother. 2014, 20, 814-816. [CrossRef] 
49. El-Herte, R.I.; Araj, G.F.; Matar, G.M.; Baroud, M.; Kanafani, Z.A.; Kanj, S.S. Detection of Carbapenem-Resistant Escherichia Coli and Klebsiella Pneumoniae Producing NDM-1 in Lebanon. J. Infect. Dev. Ctries. 2012, 6, 457-461. [CrossRef]

50. Baroud, M.; Dandache, I.; Araj, G.F.; Wakim, R.; Kanj, S.; Kanafani, Z.; Khairallah, M.; Sabra, A.; Shehab, M.; Dbaibo, G.; et al. Underlying Mechanisms of Carbapenem Resistance in Extended-Spectrum $\beta$-Lactamase-Producing Klebsiella Pneumoniae and Escherichia Coli Isolates at a Tertiary Care Centre in Lebanon: Role of OXA-48 and NDM-1 Carbapenemases. Int. J. Antimicrob. Agents 2013, 41, 75-79. [CrossRef] [PubMed]

51. Oteo, J.; Hernández, J.M.; Espasa, M.; Fleites, A.; Sáez, D.; Bautista, V.; Pérez-vázquez, M.; Fernández-garcía, M.D.; Delgadoiribarren, A.; Sánchez-romero, I.; et al. Emergence of OXA-48-Producing Klebsiella Pneumoniae and the Novel Carbapenemases OXA-244 and OXA-245 in Spain. J. Antimicrob. Chemother. 2013, 68, 317-321. [CrossRef] [PubMed]

52. Hammoudi, D.; Moubareck, C.A.; Aires, J.; Adaime, A.; Barakat, A.; Fayad, N.; Hakime, N.; Houmani, M.; Itani, T.; Najjar, Z.; et al. Countrywide Spread of OXA-48 Carbapenemase in Lebanon: Surveillance and Genetic Characterization of CarbapenemNon-Susceptible Enterobacteriaceae in 10 Hospitals over a One-Year Period. Int. J. Infect. Dis. 2014, 29, e139-e144. [CrossRef]

53. Matar, G.M.; Cuzon, G.; Araj, G.F.; Naas, T.; Corkill, J.; Kattar, M.M.; Nordmann, P. Oxacillinase-mediated resistance to carbapenems in Klebsiella pneumoniae from Lebanon. Clin. Microbiol. Infect. 2008, 9, 887-888. [CrossRef]

54. Al-Bayssari, C.; Olaitan, A.O.; Leangapichart, T.; Okdah, L.; Dabboussi, F.; Hamze, M.; Rolain, J.M. Whole-Genome Sequence of a BlaOXA-48-Harboring Raoultella Ornithinolytica Clinical Isolate from Lebanon. Antimicrob. Agents Chemother. 2016, 60, 2548-2550. [CrossRef]

55. Moubareck, C.A.; Mouftah, S.F.; Pál, T.; Ghazawi, A.; Halat, D.H.; Nabi, A.; AlSharhan, M.A.; AlDeesi, Z.O.; Peters, C.C.; Celiloglu, H.; et al. Clonal Emergence of Klebsiella Pneumoniae ST14 Co-Producing OXA-48-Type and NDM Carbapenemases with High Rate of Colistin Resistance in Dubai, United Arab Emirates. Int. J. Antimicrob. Agents 2018, 52, 90-95. [CrossRef] [PubMed]

56. Giske, C.G.; Fröding, I.; Hasan, C.M.; Turlej-Rogacka, A.; Toleman, M.; Livermore, D.; Woodford, N.; Walsh, T.R. Diverse Sequence Types of Klebsiella Pneumoniae Contribute to the Dissemination of Bla NDM-1 in India, Sweden, and the United Kingdom. Antimicrob. Agents Chemother. 2012, 56, 2735-2738. [CrossRef]

57. Poirel, L.; Al Maskari, Z.; Al Rashdi, F.; Bernabeu, S.; Nordmann, P. NDM-1-Producing Klebsiella Pneumoniae Isolated in the Sultanate of Oman. J. Antimicrob. Chemother. 2011, 66, 304-306. [CrossRef]

58. Morris, D.; O'Connor, M.; Izdebski, R.; Corcoran, M.; Ludden, C.E.; McGrath, E.; Buckley, V.; Cryan, B.; Gniadkowski, M.; Cormican, M. Dissemination of Clonally Related Multidrug-Resistant Klebsiella Pneumoniae in Ireland. Epidemiol. Infect. 2016, 144, 443-448. [CrossRef]

59. Paskova, V.; Medvecky, M.; Skalova, A.; Chudejova, K.; Bitar, I.; Jakubu, V.; Bergerova, T.; Zemlickova, H.; Papagiannitsis, C.C.; Hrabak, J. Characterization of NDM-Encoding Plasmids from Enterobacteriaceae Recovered from Czech Hospitals. Front. Microbiol. 2018, 9, 1549. [CrossRef]

60. Musila, L.; Kyany'a, C.; Maybank, R.; Stam, J.; Oundo, V.; Sang, W. Detection of Diverse Carbapenem and Multidrug Resistance Genes and High-Risk Strain Types among Carbapenem Non-Susceptible Clinical Isolates of Target Gram-Negative Bacteria in Kenya. PLoS ONE 2021, 16, e246937. [CrossRef] [PubMed]

61. Torres-González, P.; Bobadilla-Del Valle, M.; Tovar-Calderón, E.; Leal-Vega, F.; Hernández-Cruz, A.; Martínez-Gamboa, A.; Niembro-Ortega, M.D.; Sifuentes-Osornio, J.; Ponce-De-León, A. Outbreak Caused by Enterobacteriaceae Harboring NDM1 Metallo- $\beta$-Lactamase Carried in an IncFII Plasmid in a Tertiary Care Hospital in Mexico City. Antimicrob. Agents Chemother. 2015, 59, 7080-7083. [CrossRef] [PubMed]

62. Cristóvão, F.; Alonso, C.A.; Igrejas, G.; Sousa, M.; Silva, V.; Pereira, J.E.; Lozano, C.; Cortés-Cortés, G.; Torres, C.; Poeta, P. Clonal Diversity of Extended-Spectrum Beta-Lactamase Producing Escherichia Coli Isolates in Fecal Samples of Wild Animals. FEMS Microbiol. Lett. 2017, 364. [CrossRef]

63. Van Hoek, A.H.A.M.; Veenman, C.; Florijn, A.; Huijbers, P.M.C.; Graat, E.A.M.; de Greeff, S.; Dierikx, C.M.; van Duijkeren, E. Longitudinal Study of ESBL Escherichia Coli Carriage on an Organic Broiler Farm. J. Antimicrob. Chemother. 2018, 73, 3298-3304. [CrossRef] [PubMed]

64. Dhaouadi, S.; Soufi, L.; Hamza, A.; Fedida, D.; Zied, C.; Awadhi, E.; Mtibaa, M.; Hassen, B.; Cherif, A.; Torres, C.; et al. Co-Occurrence of Mcr-1 Mediated Colistin Resistance and $\beta$-Lactamase-Encoding Genes in Multidrug-Resistant Escherichia Coli from Broiler Chickens with Colibacillosis in Tunisia. J. Glob. Antimicrob. Resist. 2020, 22, 538-545. [CrossRef] [PubMed]

65. Fernandes, M.R.; McCulloch, J.A.; Vianello, M.A.; Moura, Q.; Pérez-Chaparro, P.J.; Esposito, F.; Sartori, L.; Dropa, M.; Matté, M.H.; Lira, D.P.A.; et al. First Report of the Globally Disseminated IncX4 Plasmid Carrying the Mcr-1 Gene in a Colistin-Resistant Escherichia Coli Sequence Type 101 Isolate from a Human Infection in Brazil. Antimicrob. Agents Chemother. 2016, 60, 6415-6417. [CrossRef]

66. Kalantar-Neyestanaki, D.; Mansouri, S.; Kandehkar Ghahraman, M.R.; Tabatabaeifar, F.; Hashemizadeh, Z. Dissemination of Different Sequence Types Lineages Harboring BlaCTX-M-15 among Uropathogenic Escherichia Coli in Kerman, Iran. Iran. J. Basic Med Sci. 2020, 23, 1551-1557. [CrossRef]

67. Al-Mir, H.; Osman, M.; Azar, N.; Madec, J.-Y.; Hamze, M.; Haenni, M. Emergence of Clinical Mcr-1-Positive Escherichia Coli in Lebanon Running Title: Mcr-1-Positive E. Coli in Lebanese Patients. J. Glob. Antimicrob. Resist. 2019, 19, 83-84. [CrossRef] [PubMed]

68. Chaalal, N.; Touati, A.; Yahiaoui-Martinez, A.; Aissa, M.A.; Sotto, A.; Lavigne, J.-P.; Pantel, A. Colistin-Resistant Enterobacterales Isolated from Chicken Meat in Western Algeria. Microb. Drug Resist. 2021. [CrossRef] 
69. Elmonir, W.; Abd El-Aziz, N.K.; Tartor, Y.H.; Moustafa, S.M.; Abo Remela, E.M.; Eissa, R.; Saad, H.A.; Tawab, A.A. Emergence of Colistin and Carbapenem Resistance in Extended-Spectrum $\beta$-Lactamase Producing Klebsiella Pneumoniae Isolated from Chickens and Humans in Egypt. Biology 2021, 10, 373. [CrossRef]

70. Okdah, L.; Leangapichart, T.; Hadjadj, L.; Olaitan, A.O.; Al-Bayssari, C.; Rizk, R.; Hammoud, M.; Diene, S.M.; Rolain, J.M. First Report of Colistin-Resistant Klebsiella Pneumoniae Clinical Isolates in Lebanon. J. Glob. Antimicrob. Resist. 2017, 9, 15-16. [CrossRef]

71. Nawfal Dagher, T.; Al-Bayssari, C.; Chabou, S.; Baron, S.; Hadjadj, L.; Diene, S.M.; Azar, E.; Rolain, J.M. Intestinal Carriage of Colistin-Resistant Enterobacteriaceae at Saint Georges Hospital in Lebanon. J. Glob. Antimicrob. Resist. 2020, 21, 386-390. [CrossRef] [PubMed]

72. Nawfal Dagher, T.; Azar, E.; Al-Bayssari, C.; Chamieh, A.S.; Rolain, J.M. First Detection of Colistin-Resistant Klebsiella Pneumoniae in Association with NDM-5 Carbapenemase Isolated from Clinical Lebanese Patients. Microb. Drug Resist. 2019, 25, 925-930. [CrossRef] [PubMed] 